\title{
ДОСЛІДЖЕННЯ КОНСТРУКЦІЙ СТРУМЕНЕВИХ ЖИВИЛЬНИКІВ ЛИСТОВОГО МАТЕРІАЛУ
}

(๖) Я. І. Проць, к.т.н., професор, П. С. Федорів, асистент, Ю. О. Цяпута, аспірантка, В. В. Скочиляс, аспірант, Тернопільський національний технічний університет імені Івана Пулюя, Тернопіль, Україна

В работе проведен анализ процесса отделения и подачи листового материала с помощью струйно-фрикционных питателей разных конструкций, в основу работы которых положен принцип возникновения аэродинамического эффекта при вытекании из сопла струи воздуха. Определены основные конструктивные и технологические параметры, которые определяют оптимальные режимы работы питателей для обеспечения нужной производительности подачи листовых заготовок.

In this paper the analysis of sheet material separation and supply by jet-friction feeders of different constructions, which are based on principle of aerodynamic effect of gravity during air-jet outflow from a nozzle. The main design and technological parameters, that determine the optimum operating mode of the feeders to provide the desired productivity of sheet blanks supply, were defined.

\section{Постановка проблеми}

Однією з особливих задач автоматизації виробничих процесів $€$ автоматизація процесів подачі і завантаження листових заготовок у поліграфічній, машинобудівній, приладобудівній, легкій та інших промисловостях. Висока продуктивність автоматизованих робочих машин, поєднана з надійністю, досягається тільки у тому випадку, коли механізм живлення забезпечує подачу заготовок із заданим інтервалом [1]. Для поштучного відділення листової заготовки від стопи широко використовуються вакуумні захоплювальні органи. Одним з ефективніших способів поштучного відділення листового матеріалу є струменево-фрикційний живильник, який володіє хорошими динамічними характеристиками і простотою різноманітних конструкцій для забезпечення потрібних технологічних вимог.

\section{Аналіз попередніх досліджень}

Питанням відділення листових матеріалів від стопи займалися ряд авторів [2, 3]. Дослідження принципу роботи струменевих елементів було описано в працях $[4,5]$, однак питання конструктивних рішень автоматичних живильників для поштуч- 


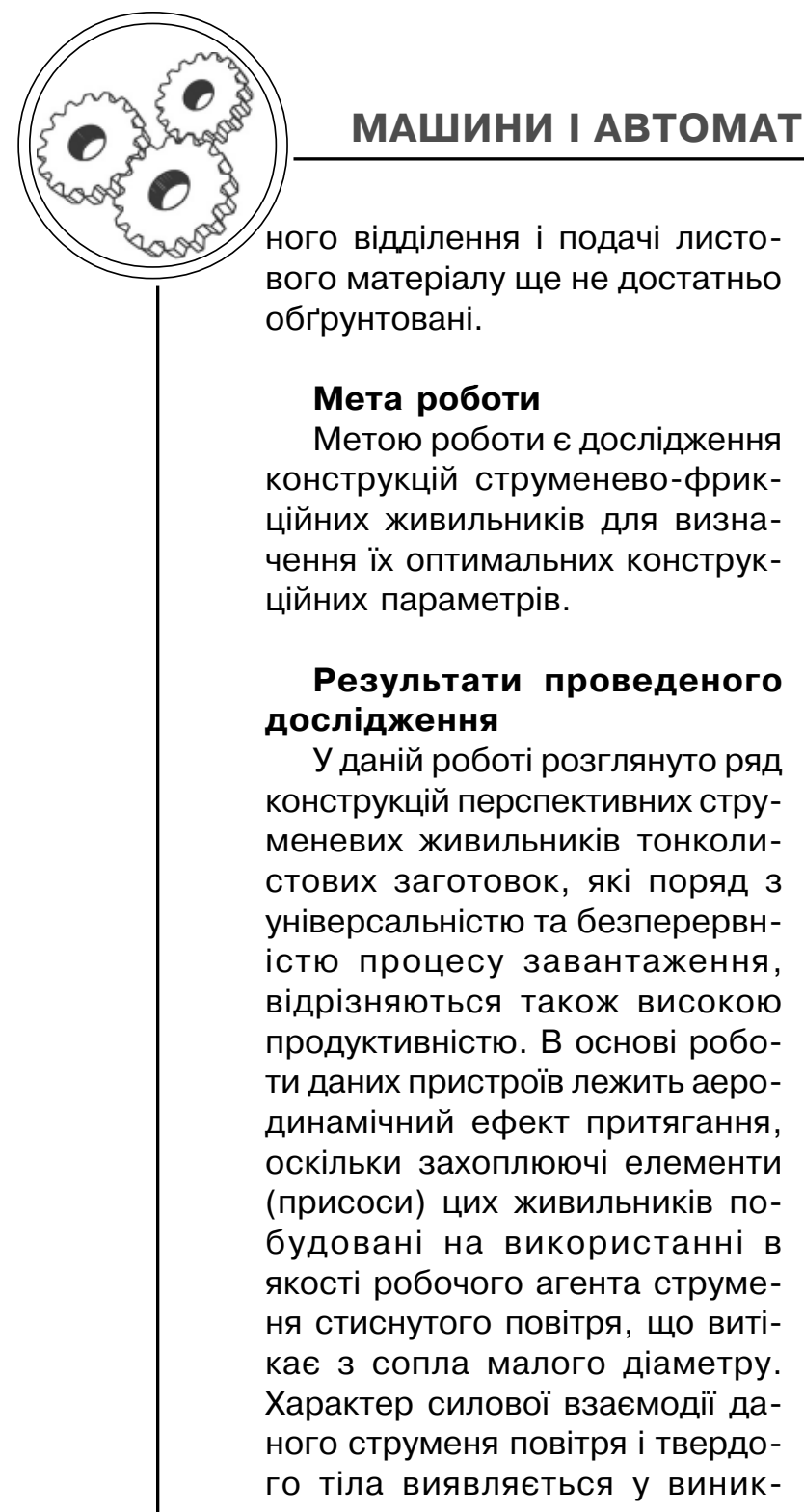

ненні реактивної і присмоктуючої сил, в'язкого тертя, повітряної подушки, прилипання струменя до обтікаючої стінки, і дозволяє створювати нові ефективні пневматичні завантажувальні пристрої для одночасного здійснення операцій поштучного відокремлення, транспортування й орієнтації деталей [4].

У результаті подачі до сопла 2 (рис. 1) стиснутого повітря постійного тиску сформований отвором-соплом радіусом $r_{c}$ і спрямований перпендикулярно площині поршня струмінь повітря протікає в щілину h між торцями струменевого елемента і заготовки 3 зі швидкістю $\mathrm{V}_{0}$ приблизно рівною місцевій швидкості звуку $\mathrm{V}_{\text {кр }}$. Переломлюючись об поверхню листа повітря в щілині перетвориться в плоский радіальний потік. Швидкість плину потоку $V_{1}$ на деякому радіусі $r$ дещо менша швидкості витікання $\mathrm{V}_{1}<\mathrm{V}_{0}$, а в міру наближення до периферії силового елемента поступово зменшується до швидкості $\mathrm{V}_{1}>\mathrm{V}_{2}$, а надалі на радіусі $r_{2}$ відбувається повне розчинення в атмосфері.

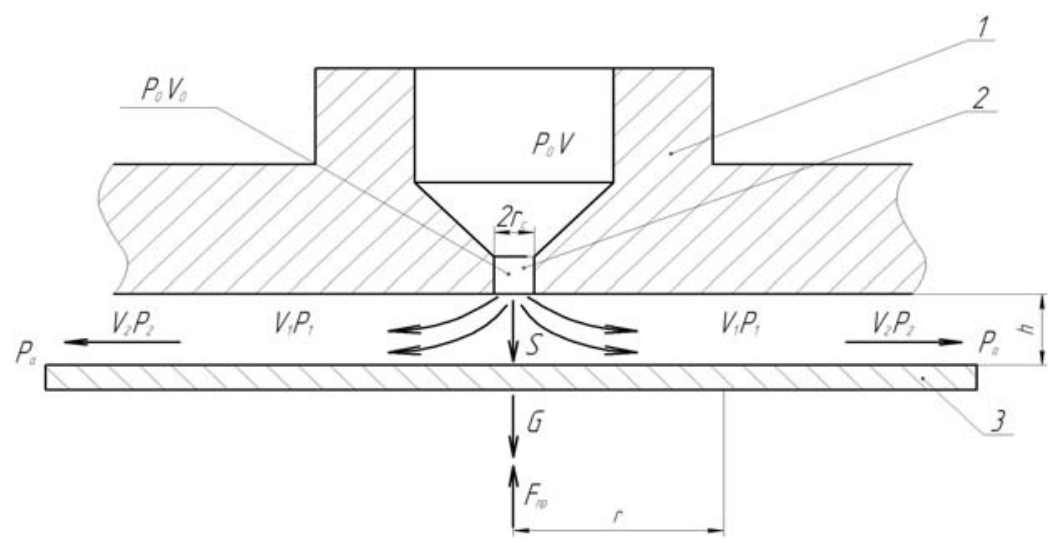

Рис. 1. Схема струменевого присоса 
Енергія рухомого суцільного кільцевого газового потоку, обумовлена повним напором, що складається із суми п'єзометричного і динамічного напорів, викликає на торці струменевого елемента зниження тиску до величини нижче атмосферного, тобто

$$
\mathrm{P}_{\mathrm{a}} \geq \Delta \mathrm{P}+\frac{\rho \mathrm{V}_{1}^{2}}{2}
$$

що сприяє при визначених конструктивних параметрах струменевих елементів появі аеродинамічного ефекту притягання.

Під його дією лист силою присмоктування 3 визначеної відстані піднімається нагору і притискається до торця соплового елемента. Лист не знаходиться в безпосередньому дотику з торцем силового механізму, а вільно плаває на повітряній подушці автоматично підтримуючи зазор $\mathrm{h}$ товщиною порядку 0,08...0,12 мм. Зусилля присмоктування $\mathrm{F}$ залежить від схеми розподілу швидкостей і тиску радіального суцільного потоку газу, обумовлених характером плину до периферії сопла, де тиск дорівнює атмосферному $\mathrm{P}_{\mathrm{a}}$, а втрати на тертя виража- ються в гальмуванні потоку і зміні об'ємних витрат повітря крізь зазор $\mathrm{h}$.

У загальному, основною задачею розрахунку струменевих присосів і живильників є визначення залежності між необхідним тиском та величиною присмоктуючої сили, зовнішніми силами протидії присмоктуванню заготовок та їх геометричними параметрами, кількістю одночасно діючих присосів та характером витікання із них струменів та інше.

Конструкції струменевих живильників можуть базуватися на самоточних і примусових схемах переміщення заготовок. Конструктивно вони виконуються в вигляді повітророзподільної камери 1 (рис. 2), нижня несуча поверхня 2 якої має один або декілька рядів циліндричних або кільцевих отворів 3, розміщених перпендикулярно (в самоточних) або під певним кутом до несучої поверхні в напрямку руху виробів 4 (у примусових) [6].

Враховуючи те, що маса вантажу, який піднімається і транспортується аеродинамічним живильником, визначається різницею атмосферного тиску під виробом і тиском повітряної по-

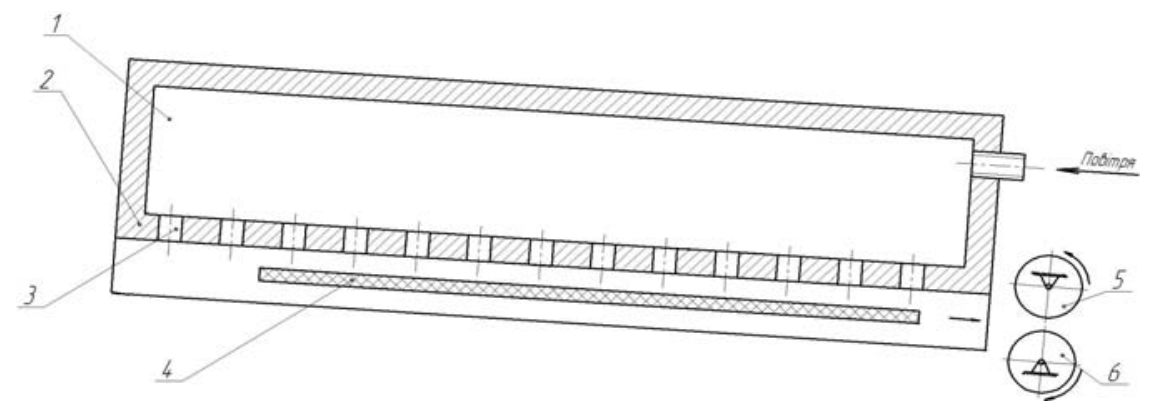

Рис. 2. Живильник із перпендикулярним розміщенням сопел 
душки над заготовкою, рекомендується для додаткового збільшення підйомної сили створювати зони постійного тиску у повітряній подушці. Це досягається тим, що в аеродинамічних живильниках отвори розміщують в два поздовжніх ряди по периферії несучої поверхні. Експериментальні дослідження показали, що при ширині несучої поверхні до 50 мм необхідно розмістити сопла на відстані I = 2 мм від бокових направляючих.

Застосування в несучій поверхні отворів нахилених під кутом $\beta$ в поздовжньому напрямку і під кутом в в поперечному напрямку забезпечує максимальну вантажопідйомність струменевих живильників (рис. 3).

Для транспортування виробів, довжина яких k, необхідно несуча поверхня шириною $\mathrm{L}+2 \mathrm{l}$, де $\mathrm{L}$ - поперечна відстань між паралельними рядами отворів. Нехтуючи стисканням повітря і вважаючи його рух ламінарним і постійним, з допомогою рівняння Бернуллі знаходимо розподіл тиску повітря в поперечному перерізі повітряної подушки. В такому випадку загальна підіймальна сила аеродинамічного конвеєру буде:

$$
\begin{aligned}
& \mathrm{G}=\pi(\mathrm{L}+2 \mathrm{l}) \mathrm{kP}_{a}-\mathrm{kL} \cdot \\
& \cdot\left\{\mathrm{P}_{\mathrm{n}}-\frac{\rho \mathrm{Q}^{2}}{2}\left[\frac{1}{\mathrm{~S}^{2}}-\frac{1}{(\pi \mathrm{rh})^{2}}\right]\right\},
\end{aligned}
$$

де $\rho$ - густина повітря; $P_{a}$ - атмосферний тиск; $P_{n}$ - тиск повітря в камері; S - площа перерізу даної камери; Q - розхід повітря через один отвір; h - висота повітряної подушки; $\mathrm{S}=\pi \mathrm{r}^{2}$ - площа перерізу одного отвору.

Кут $\alpha$ визначає швидкість руху виробів. На заготовки діють сила динамічного тиску повітря, сила тертя виробів об повітря і тертя об повітряну подушку. Так як друга і третя сили малі порівняно 3 силою динамічного тиску, то саме остання сила в основному і визначає параметри руху виробів по аеродинамічному живильнику.

Величини прискорення $\alpha$, швидкості V і шляху H, що пройшов виріб в залежності від часу t в конвеєрах з підвищеною вантажопідйомністю, можуть бути

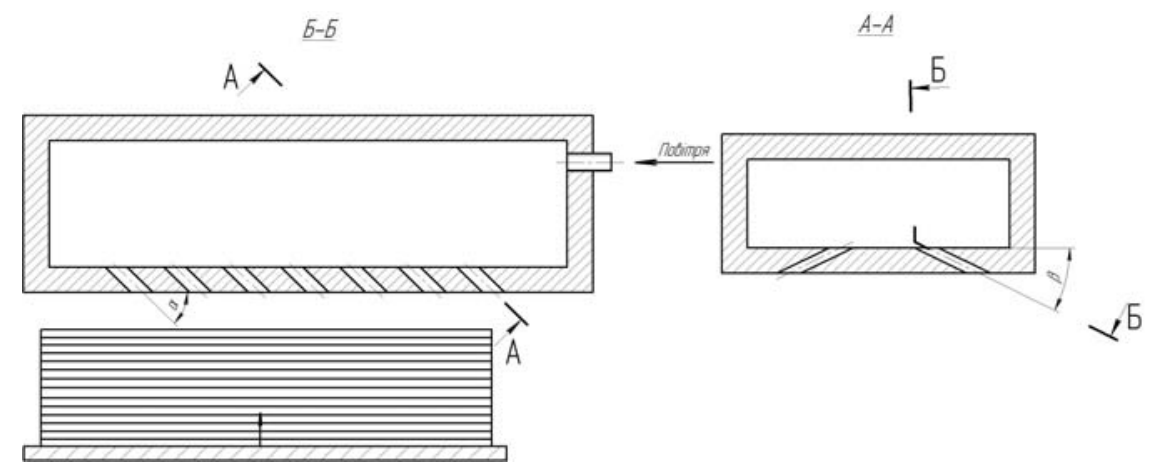

Рис. 3. Живильник із косим розміщенням сопел 
визначені за наступними формулами:

$$
\begin{gathered}
\mathrm{a}=\frac{2 U \sin \alpha \mathrm{Pq} \mathrm{e}^{\mathrm{Pt}}}{\left(\mathrm{e}^{2 \mathrm{Pt}} \mathrm{q}^{2}-1\right)} \\
\cdot\left(\frac{2 \mathrm{q}^{2} \mathrm{e}^{2 \mathrm{Pt}}}{\mathrm{e}^{2 \mathrm{Pt}} \mathrm{q}^{2}-1}-1\right) \\
\mathrm{V}=\mathrm{U} \cos \alpha-\frac{2 \mathrm{U} \sin \alpha \mathrm{e}^{\mathrm{Pt}} \mathrm{q}}{\left(\mathrm{e}^{2 \mathrm{Pt}} \mathrm{q}^{2}-1\right)} \\
\mathrm{H}=\mathrm{U} \cos \alpha \mathrm{t}+\frac{\mathrm{U} \sin \alpha}{\mathrm{P}} . \\
\ln \frac{\left(1-\mathrm{q} \mathrm{e}^{\mathrm{Pt}}\right)(1-\mathrm{q})}{\left(1-\mathrm{q} \mathrm{e}^{\mathrm{Pt}}\right)(1+\mathrm{q})} \\
\mathrm{P}=\frac{\rho \pi l^{2} \cos \alpha \sin \alpha b U}{M(f+2 l)} \\
q=\frac{1+\sin \alpha}{\cos \alpha},
\end{gathered}
$$

де $\mathrm{M}$ - маса виробу; $f$ - повздовжня відстань між отворами; U - швидкість витоку повітряних струменів з отворів; b - висота виробів; $r$ - радіус отвору.

Експериментальні дослідження [6] показали, що розподіл сопел під кутом $\beta<20^{\circ}$ дозволяє збільшити вантажопідйомність живильників у 2 рази.

Конструкція живильника автоматичної поштучної подачі плоских заготовок на робочу позицію (рис. 4), в основу якого покладений струменевий захоплюючий механізм, який містить вертикальний стапельний стіл 1 із дискретним пневматичним приводом, на якому розміщена стопа заготовок 2.

Над столом встановлений струменевий присос у вигляді горизонтальної плити 3, в нижній частині якої перпендикулярно площині заготовок виконані отвори-сопла 4 діаметром 1-4 мм, з'єднані загальною камерою 5 для подачі стиснутого повітря постійного тиску. При витіканні з отворів струменів повітря за рахунок появи в зоні торця присмоктуючої сили заготовка з відстані H $(\mathrm{H} \leq 15$ мм) буде піднята вверх і притиснута до фрикційного пасу 6, який виступає на певне значення $\mathrm{h}$ над корпусом захоплювача.

Для транспортування заготовок у власній площині встановлені безперервно обертові ролики 7 і 8, які приводять в рух фрикційний пас. Під ремені в корпусі камери зроблено виїмку для зменшення тертя 3 корпусом. Для зменшення сил зчеплення між захопленою 9 i наступною 10 заготовками перед стопою встановлено розпушувач 11.

Подальше транспортування поштучно відділених заготовок у бік робочої позиції машини відбувається приймаючими 12 і транспортуючими 13 фрикційними роликами, які безперервно обертаються із швидкістю, регламентованою продуктивністю.

Швидкодія живильника поштучної видачі визначається сумою часу $t_{1}$ руху верхньої заготовки від стопи до площини

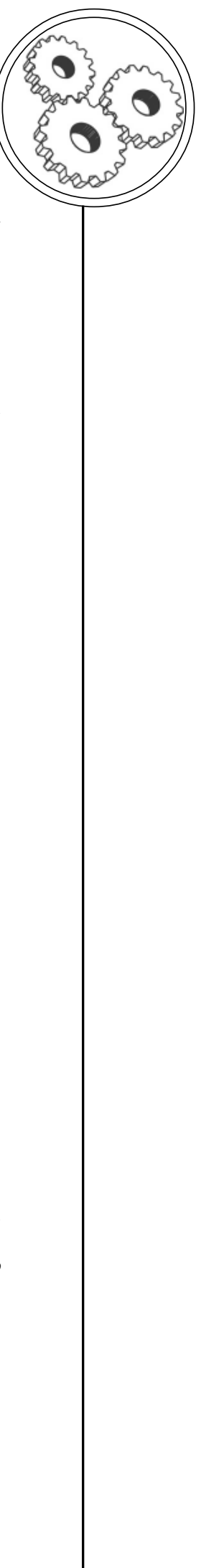




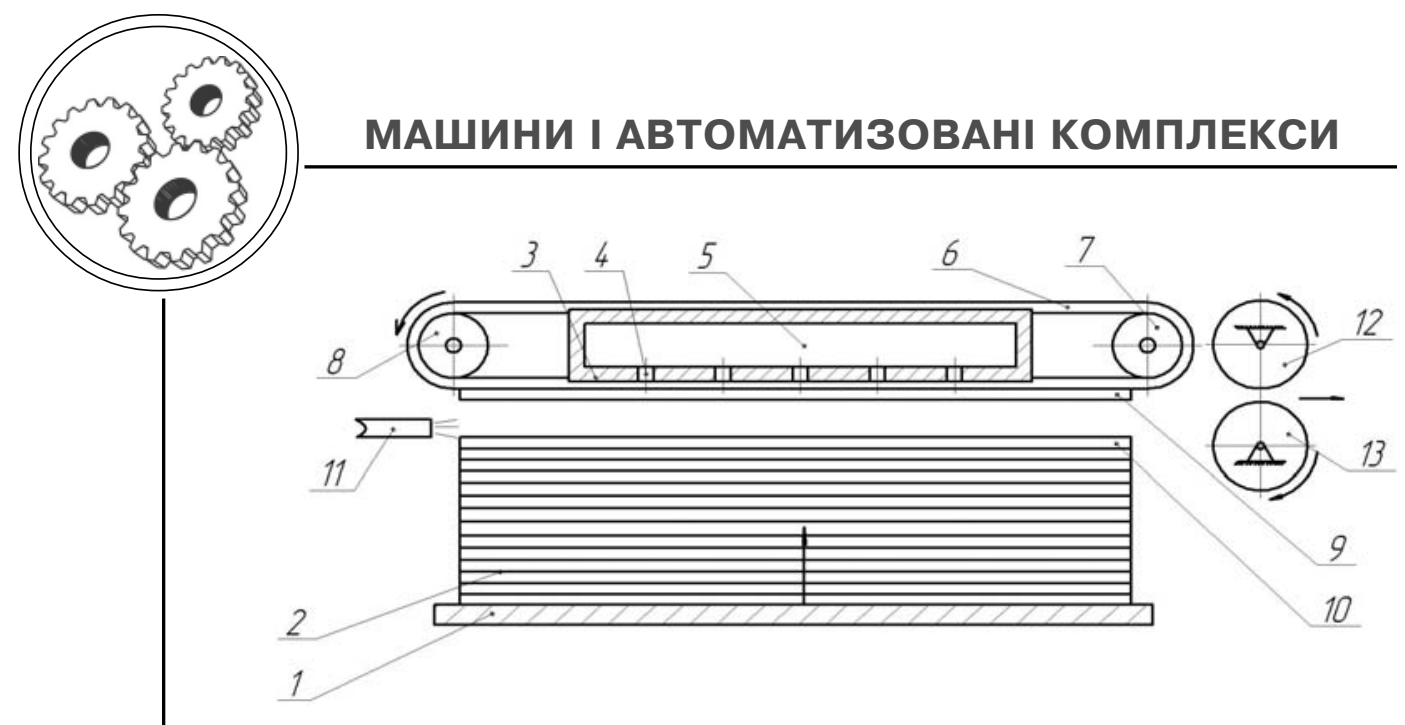

Рис. 4. Конструкція автоматичного живильника на основі струменевих елементів

торців отворів-сопел 4 під присмоктуючою дією витікаючих із неї струменів і часу $\mathrm{t}_{2}$ транспортування заготовки у власній площині до приймаючих роликів 11 [7]. Розглядаючи характер руху заготовки у вертикальному напрямку під дією струменевого елемента та характер лінійного переміщення, можна визначити $t_{1}$ i $_{2}$, які сумарно визначать продуктивність.

Більшої вантажопідйомності живильника можна досягнути збільшивши аеродинамічний ефект притягання, що конструкційно вирішується шляхом висування сопел над площиною корпусу камери. В даному випадку реактивна сила зменшена, а аеродинамічний ефект зростає. Фрикційний пас проходитиме між соплами, що теж зменшує трудомісткість вико- нання даної конструкції. Кількість сопел і пасів залежить від величини і маси заготовок, що захоплюються.

\section{Висновки}

За аналітичними й експериментальними дослідженнями [3] струменеві присоси, у порівнянні з найбільш близькими за принципом роботи і широко вживаними, - вакуумними, мають ряд переваг: високу точність базування заготовок, кращі динамічні характеристики, відсутність рухомих елементів і додаткових механізмів цільового призначення для транспортування заготовки та ін. Завдяки цьому вони можуть бути використані при автоматизації технологічних процесів у машинобудівній, приладобудівній, легкій, поліграфічній та інших промисловостях.

1. Корсаков В. С. Автоматизация производственных процессов. Уч. пос. для вузов / В. С. Корсаков. - М. : Высшая школа, 1973. - 215 с. 2. Бляхеров И. С. Автоматическая загрузка технологических машин : Справочник / И. С. Бляхеров, Г. М. Варьяш, А. А. Иванов и др.; Под общ. ред. И. А. Клусова. - М. : Машиностроение, 1990. - 400 с. 3. Перекалин И. М. Устройство для отделения тонких листовых изделий, уложенных в стопки, и поштуч- 
ной их выдачи / И. М. Перекалин, А. В. Рыбаков - Патент Российской Федерации, 1997. - 5 с. 4. Козловский М. А. Присасывающее действие струи, обтекающей пластинку / М. А. Козловский // Приборостроение. Киев : Техніка, 1966. - Вып. 2. - С. 197-199. 5. Сентяков Б. А. Исследование силовых характеристик струйного вихревого преобразователя / Б. А. Сентяков, Г. П. Исупов. - М. : Измерительная техника. - 1984. № 1. - 34 с. 6. Битюков В. К. Аэродинамические конвейеры / В. К. Битюков // Механизация и автоматизация производства. - 1981. - № 10. С. 11. 7. Проць Я. И. Скоростная струйная подача картонных сторонок при изготовлении переплетных крышек / Я. И. Проць, М. А. Козловский, М. Г. Дычковский и др. // В сб. : Исследования и разработки в полиграфической промышленности. - Л. : Изд-во Львов. ун-та. - 1973. - С.144150.

Рецензент - П. О. Маршак, д.т.н., профессор, ТНТУ ім. І. Пулюя

Надійшла до редакції 17.02.12 